\title{
ANALYSIS OF THE ORGANIZATIONAL STRUCTURE OF A NONPROFIT ORGANIZATION MANAGEMENT IN THE CONTEXT OF UKRAINIAN GREEK CATHOLIC CHURCH
}

\author{
Volodymyr Kharko ${ }^{1}$ \\ Myron Andrushchyshyn²
}

DOI: https://doi.org/10.30525/978-9934-26-021-6-22

Abstract. This article is devoted to the study of the organizational structure of the Ukrainian Greek Catholic Church (hereinafter UGCC) as the largest Eastern Catholic Church of the Byzantine rite in the world. The UGCC belongs to religious organizations (hereinafter RO), which form a separate subgroup in the general structure of non-profit organizations (hereinafter NGOs) and, accordingly, constitute the third sector of the economy along with government agencies and commercial organizations.

When considering the theoretical issues, the article presents the development and evaluation of scientific thought, the theory of research and the functioning of organizational structures. The essence of organizational management structures is revealed, in particular their basic elements, interrelations, as well as the fundamentals of formation and designing.

In what follows, the system of general ecclesiastical administration of the Catholic Church is presented, where the power of leadership, or administration, is divided into three categories: legislative, judicial and executive, combined as a whole in the person of the pope and at the level of the Bishop's Particular Church.

The article also reveals the place and status of the Eastern Catholic Churches in the general structure of the Catholic Church, where synodal administration is considered to be a usual form of government. This form of government operates through an episcopal system based on the hierarchy of bishops and their unification into a college (synod) headed by the head of the church.

\footnotetext{
${ }^{1}$ Department of Management, Ivan Franko National University of Lviv, Ukraine

${ }^{2}$ Department of Management, Ivan Franko National University of Lviv, Ukraine ORCID: https://orcid.org/0000-0002-3877-084X
} 
In the analysis of statistical data on the development of structures and personnel of the UGCC for the last two decades, the quantitative growth of the clergy and the quantitative growth of parishes for this period are graphically presented, which testifies to the stable and professional development of organizational structures and personnel (clergy) of the UGCC in the world.

When analyzing church documents (normative-legal acts) regulating the activities of the UGCC and comparing them with theoretical developments in the field of management of organizational structures, it should be noted that OSU UGCC belongs to bureaucratic structures with decentralized operational management at the local level. From the point of view of the analysis of the hierarchy of power, the main governing bodies of the UGCC are described, where the status of each governing body and official is clearly regulated by church canons and job descriptions of the UGCC.

\section{Introduction}

International practices of countries with developed economy suggest that the activity of nonprofit organizations and charitable institutions is an important element of society development.

Since its independence, Ukraine has experienced a highly dynamic growth of religious organizations. It was especially the case when Ukraine was only gaining its independence and amidst the period of social and economic crises of the last decades, during which RO had played a pivotal role in supporting and protecting country's citizens. For this reason, religious organizations and religious figures have been occupying leading positions in confidence polls.

According to the current legislation [22], in Ukraine, there is a secular principle of separation of state and church which is characterized by noninterference of both parties in each other's affairs. However, it presupposes cooperation between the church (religious organizations) and state, which is regulated by normative legal acts [1].

The secular principle entails a certain responsibility for the RO, which do not rely on the government's assistance and are completely self-dependent. As a result, the UGCC requires considerable financial resources in order to conduct various activities as well as support and develop its organizational 
structures. The aforementioned resources are received from congregation's offerings, commercial entities, specialized international foundations and programs. This urges the RO to constantly search for resources to support their activities and develop their structures.

In view of its organizational and legal mode of activity, the Ukrainian Greek Catholic Church (henceforth UGCC) belongs to religious organizations (henceforth RO), which constitute a separate subgroup in a general structure of nonprofit organizations. The study of the organizational structure of the UGCC as the largest Byzantine Rite Eastern Catholic Church in the world is indeed crucial and essential considering its peculiar management, areas of activity and a well-developed network of religious structures.

\subsection{Urgent scientific solutions}

Scientific literature offers rather extensive coverage of theoretical and methodological foundations of the formation of organizational structures conducted by theorists in this field.

For instance, famous American management theorist Peter Drucker and modern American economist Richard L. Daft is convinced that it is necessary to move away from the concepts of classical management characterized by the universalist view, in which efficient management concepts in one organization (whether based on the style of leadership or a bureaucratic structure) will yield the same positive results in another. $\mathrm{He}$ is in favour of implementing the so-called contingency view into business education. This view is based on the principle that managers face the task of determining what methods will work in every new situation [33, p. 57; 34, p. 114].

Furthermore, T. Norbert in his work 'Change management' states that organizational structure is the most stable and conservative feature of the management system, which remains unchanged for a long time despite changes in the system itself. However, business practice shows that organizational structure of an enterprise is not rigid and permanent since it is affected by changes and subsequently adapts and improves in accordance with changing external conditions [29].

Attention should also be paid to the theory of designing organizational structures of an organic (strategic) type, which were laid down by such 
scientific theorists as R. Akoffa and G. Mintzberg. They proved that it is necessary to create such a «framework» for the company, which will ensure its successful and long-term existence in the future. Such structures should avoid excessive bureaucratization, contain an effective distribution of responsibilities among management personnel and the creation of an effective control system [3].

The practical experience of solving urgent problems in the direction of improving organizational structures is presented in the works of the famous Japanese researcher T. Kono in his work, which is of an applied nature, uses the existing theoretical developments of American and Western European scientists at that time. The author has generalized significant factual material for the conditions of Japanese enterprises, considering the national characteristics of the formation of management, for example, the selection and hiring of personnel, subordination relations in labor activity [3].

In addition, it is important to pay attention to approaches concerning organizational structures developed by Michael Mescon, Michael Albert, and Franklin Khedouri. These scientists emphasize that the best organizational structure is the one that helps the company to effectively interact with the external environment, productively distribute and direct the efforts of its employees, and thus meet the needs of customers and achieve the set objectives with high efficiency [29].

The work of DG Konokov and MA Rozhkov "Organizational structure of enterprises", where the attempt was made to optimize the organizational structure of an enterprise by substantiating the necessary changes in it and the mechanisms of its formation, is of undoubtedly applied and theoretical interest [3].

Analysis of the results from scientific research gives the freedom to state that in view of various market situations and circumstances that the external environment and modern business conditions create, it is necessary to emphasize that a universal solution for the establishment or implementation of a certain OS model in the enterprise management proves to be impossible. Therefore, the choice of the optimal organizational structure would depend on the ability of an enterprise to dynamically respond to changes or fluctuations in the external environment and effectively interact with it. 


\subsection{Research task}

Research task of this paper is to analyze the organizational structure and management apparatus of the Ukrainian Greek Catholic Church as the largest Byzantine Rite Eastern Catholic Church in order to lay the groundwork for implementation of effective changes in the general organizational structure of UGCC.

It is also important to outline the issues connected with the organizational structure of the UGCC, which is presented through the prism of two components - the internal and external environment.

Nowadays, the UGCC is increasingly faced with the questions of adapting its activities and internal structures to new challenges, requirements and needs of liturgical service in the rapidly developing world. In order to effectively respond to the constantly emerging changes, the UGCC should improve and reorganize its structures, management system, and provision of religious services because of the relevant needs and circumstances that are to be addressed in the modern world.

Secondly, the tasks that the UGCC had faced after the collapse of the Soviet Union were initially connected with the reclamation and restoration of places of worship, the registration of faith communities, and the revival of spiritual life among the Christians. After the legalization of the UGCC and its official recognition by the state and the Vatican as a legitimate religious organization with its canon law, an urgent issue arose due to the restoration of Church religious centres and management structures. This process is characterized by the gradual development of UGCC structures, the quality of conducting religious services and implementing efficient management, which allowed the UGCC as one of the major archiepiscopal churches to claim the status of the patriarchate, which is the supreme stage of prestige and self-government.

\subsection{Methodology}

The research relies on general scientific approaches and methods of enquiry. In particular, the research implements: historical and logical approach in identifying the origins and development of scientific thought of the theory study and operation of OS (part 1); analysis and synthesis methods so to identify the most significant features of the activities of religious organizations, the basic structure of the Church, the organizational 
structure in the Catholic Church, particularly in the areas where UGCC predominates; the statistical method is used to collect quantitative data on the presence of UGCC structures in the world, with subsequent analysis, aggregation and estimation of data. A graphical method for visual presentation and demonstration of statistical data on UGCC structures is applied in order to summarize and analyze the nature of current trends and relationships between them.

It is worth noting that due to certain conditions, such as inadequate exploration of UGCC's OS by scientists, the study of UGCC's OS is conducted while taking into account much better researched classical management theory and the canon law of the Catholic Church, which would allow us to present the peculiarities of UGCC organizational structure as well as its main elements in detail.

\subsection{Structure}

Major sources of references including theoretical approaches towards the notion of OS, the OS of the Church, and a brief description of the UGCC. The typology of main OS is presented as well, on the basis of which the type of the UGCC OS shall be defined in view of the canon law of the Catholic Church. Furthermore, the UGCC OS and its main elements, such as chains and levels of management and organizational relationship between them are analyzed and described according to the applied research methodology and on the basis of secular and religious normative legal acts, statistical data of the State Committee of Ukraine on Nationalities and Religions, in particular, its Report on the Network of Churches and Religious Organizations in Ukraine as of the first of January 2019, and the Annuario Pontificio, i.e. the annual statistical directory of the Holy See of the Catholic Church. Besides, this paper explores the composition of organizational departments, the division of duties and responsibilities between ranks, and the hierarchy of church offices. Finally, the summary and conclusions are provided in the closing part of the paper.

\section{The notion of overall management in the Catholic Church}

The Catholic Church is the largest religious organization in the world with its own complex management system, which is headed by the Pope's Holy See and subordinate bishops [15, canons 43 and 178]. In the Catholic 
Church, as well as in other developed states governed by the rule of law, its powers are separated into three branches: legislative, executive and judicial. However, one should note that the separation of the branches of power in the Catholic Church does not stipulate for their complete independence, as it is the case with the majority of countries. On the contrary, they respond to the will of the Holy See and act accordingly.

The aim of organizational structures is to coordinate and control the activity of departments and employees of an enterprise. The study of organizational structures involves the following notions: elements, relationships, levels, and responsibilities. Individual employees, functional departments, and management bodies or services may be classified as elements of organizational structures.

The relationships between the elements of structures are maintained due to connections, which are divided into two types: horizontal and vertical. The former has one level and nature of an agreement. The latter designate relationships between the superior and subordinate elements and function as channels for information concerning making decisions and accounting for their implementation [17, p. 178].

Established connections may be linear and functional. Linear connections reflect the flow of managerial decisions and information between managers, i.e. agents responsible for activities of an organization or its structural departments. Functional connections refer to connections between seniors and subordinates which link hierarchical levels and serve as channels of information concerning making decisions and accounting for their implementation. The need for such connections arises when hierarchical management system with different levels of management is established [17, p. 178-179].

In fact, general management of the Catholic Church is performed at such management bodies as the College of Cardinals, Synod of Bishops and Roman Curia. They form the central administrative body of the Catholic Church, which comprises congregations, ecclesiastical courts and other institutions. The Pope together with the Roman Curia constitute the Holy See [15, canons 46]. According to the international law, the Holy See in Rome is recognized as a sovereign entity located in the independent Vatican City State [19].

The Roman Catholic Church comprises the particular Churches of Latin and Eastern rites, which hold service in one of the Eastern liturgical rites 
and have the status of sui iuris ${ }^{1}$, i.e. of one's own right, or autonomous. This enables churches sui iuris to maintain their own laws known as the Code of Canons of the Eastern Churches (henceforth CCEC) ${ }^{2}$ and the Particular $\mathrm{Law}^{3}$, have their own hierarchical structure and a separate management system that reflects certain peculiarities and the importance of the churches sui iuris in the General structure of the Catholic Church [36, p. 50].

In view of their status and degree of autonomy, Eastern or Oriental Catholic Churches sui iuris are divided into:

- Patriarchal Churches;

- Major Archiepiscopal Churches;

- Metropolitan Churches sui iuris;

- and other churches sui iuris [36, p. 89].

In the Patriarchal and Major archiepiscopal Eastern Catholic Churches, the administration is usually performed by the synodal form of management. Such form of management operates within the boundaries of the episcopal system, which is based on the hierarchy of bishops who are members of a Council or Synod led by the Visible Head of the Church in accordance with the general agreement of the Holy See.

Headed by a patriarch or major archbishop, synods of Patriarchal and Major archiepiscopal Churches constitute the supreme authority in respective particular Churches. Even though their authority overlaps to a certain extent, the division generally concerns the following aspects: a patriarch or major archbishop is endowed with the executive power while a synod of bishops holds the supreme legislative and judicial authority [36, p. 143].

\subsection{General description of UGCC}

The official legalization of the Ukrainian Greek Catholic Church took place in 1989, which made it possible to restore the internal infrastructure of the UGCC over the next five years. Thus, in 1995, the UGCC already included six dioceses with more than five million believers [35]. The

\footnotetext{
${ }^{1}$ A group of Christian faithful united by a hierarchy according to the norm of law which the supreme authority of the Church expressly or tacitly recognizes as sui iuris is called in this Code a Church sui iuris [15, canons 27].

${ }^{2}$ The Canon Law of the Catholic Church, common to all Eastern Catholic Churches, approved by Pope John Paul II in the Apostolic Constitution of Sacri Canones on October 18, 1990, which entered into force on October 1, 1991 [36, p. 43].

${ }^{3}$ This is a code of canons of the Particular Churches, which regulates other issues that contradict the CCEC and are not previously specified by the Holy See [36, p. 40].
} 
religious center of the UGCC was initially based in Lviv, but later was officially transferred to Kiev (2005), where the main management bodies and management apparatus.

UGCC is one of the largest Eastern-rite churches in the world, which maintains full communion with the Catholic Church in Rome. UGCC is a subject to the common and Catholic canon law, while also being guided by its canon, i.e. the Canons of the Particular Law of the UGCC, the statutes of the synod of bishops of the UGCC and the synod of bishops of the KyivHalych major archeparchy.

The internal structure of the UGCC is characterized by the division into separate administrative territorial units. On the lower level, there are church parishes, which are subsequently united in view of their territorial position into deaneries, vicariates, exarchates, and eparchies. The latter form regional or provincial archeparchies, the largest units of the UGCC also known as metropolitan archdioceses, or metropolitanates [15, canons 55-56, 133, § 1, 177, 276-278, 279, 311-315].

All administrative territorial units of the UGCC mentioned above have a certain degree of autonomy in the management which is specified in the Code of Canons of the Eastern Churches, internal canons of its subordinate organizations and common law.

While analyzing the trends and changes in the UGCC over the last two decades, it is important to mention that its activity is characterized by continuous growth and increase in the variety of activities and types of religious services that have a rather complex nature and delivery procedure. As may be seen from the analysis of statistical data from the Annuario Pontificio, i.e. the annual statistical directory of the Holy See of the Catholic Church, UGCC has 7 archeparchies, 21 eparchies, 5 archepiscopal exarchate, 2 apostolic exarchate and approximately 4.7 million worshippers [32, p. 8, 121, 163, 225, 225, 295, $310,321,345,357,368,379,421,423,503,520,561,584,623,626,628,629$, 634, 661, 677, 697, 705, 706, 729, 741, 792, 795, 1012, 1013].

As noted above, the organizational structures of the UGCC are present and operate at the international level. Figures 1 and 2 below show data on the quantitative growth of parishes and clergy over the past two decades. $[32$, p. $8,121,163,225,225,295,310,321,345,357,368,379,421,423$, $503,520,561,584,623,626,628,629,634,661,677,697,705,706,729$, $741,792,795,1012,1013 ; 35]$. 


\section{Parisches of UGCC}

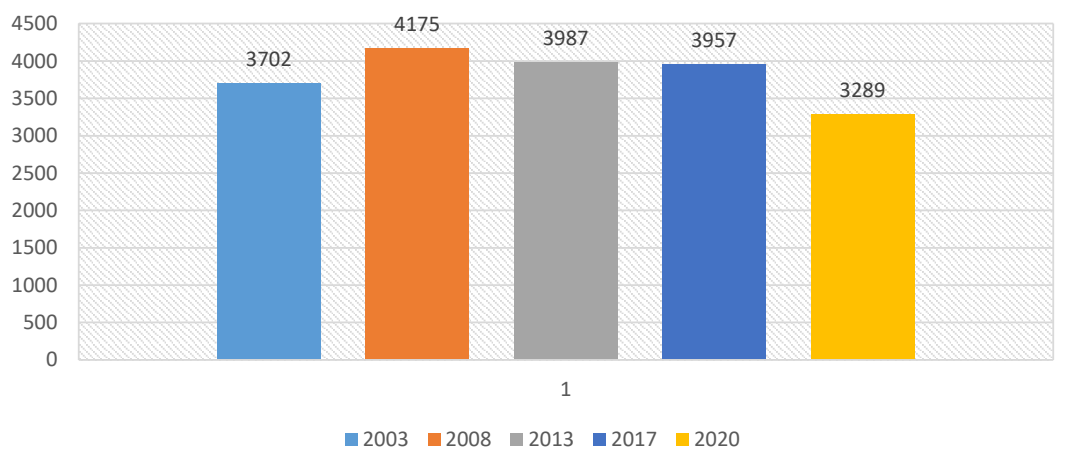

\section{Figure 1. Number of parishes in the UGCC}

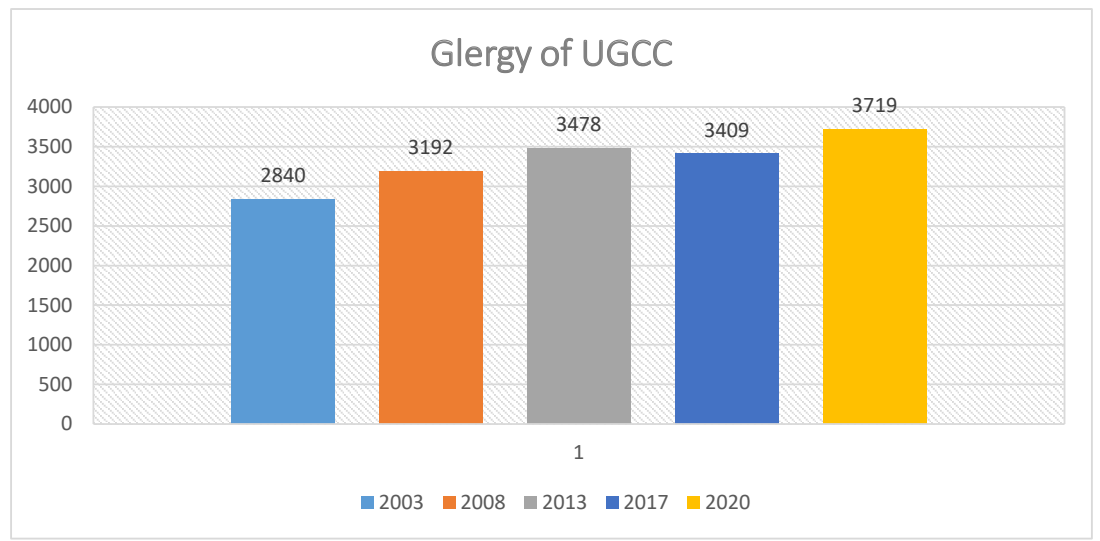

Figure 2. Number of clergy in the UGCC

Thus, since 2000 we can observe a distinct tendency towards the expansion of the UGCC structures and increase in the number of personnel, i.e. the clergy who take part in the management of the UGCC. However, it is worth mentioning that since 2013 the religious activity has stabilized, and the growth of UGCC structures is happening at a low pace both in Ukraine and abroad. 


\subsection{Definition of the kind and type of the organizational structure of the UGCC}

There has been considerable interest in the scientific description of various types of organizational structures. In general, modern management theory recognizes the following two main types of OS: adaptive and hierarchical (mechanical, bureaucratic) structures. The hierarchical kind of OS indicates an unchanging hierarchy of power, which follows commonly accepted rules, modes and procedures in enterprises combined with the centralization of management. Hierarchical OS comprises of the following types: linear, linear and functional, linear and staff, divisional OS (see table 1).

Table 1

Typology of hierarchical or bureaucratic of organizational structures [5]

\begin{tabular}{|c|c|}
\hline \multicolumn{2}{|r|}{ Hierarchical or bureaucratic: } \\
\hline Linear & $\begin{array}{l}\text { Highly centralized with rigid management. Has only linear } \\
\text { connections between its members. Decisions are taken and their } \\
\text { implementation is controlled by the centre. }\end{array}$ \\
\hline Functional & $\begin{array}{l}\text { Structural units are divided in view of their functions; existence } \\
\text { of two-way functional relationships between them. Regulation of } \\
\text { relations between functional managers is performed at the highest } \\
\text { level of management. }\end{array}$ \\
\hline $\begin{array}{l}\text { Linear and } \\
\text { functional }\end{array}$ & $\begin{array}{l}\text { Combination of linear and functional structures. Is based on the } \\
\text { separation of power and responsibility in view of intended functions } \\
\text { while main decisions are taken at the highest levels. }\end{array}$ \\
\hline Divisional & $\begin{array}{l}\text { Combines centralized coordination and control of activities with } \\
\text { decentralized management. The senior levels of management are in } \\
\text { charge of strategic tasks concerning the development of a company } \\
\text { while lower levels control autonomous units or divisions }\end{array}$ \\
\hline
\end{tabular}

On the other hand, adaptive model of organization is characterized by flexibility, decentralized management having few vaguely defined levels, rules and procedures at the enterprise. Among adaptive or organic organizational structures, one may single out matrix, project-oriented or projectized, and network OS. (see table 2).

While fusing theoretical data from aforementioned types of OS with normative legal acts of the Catholic Church, in particular with the Canon law of the Catholic Church and the Code of Canons of the Eastern Churches, 
Typology Adaptive or organic of organizational structures [17, p. 187]

\begin{tabular}{|c|l|}
\hline \multicolumn{1}{|c|}{ Adaptive or organic: } \\
\hline Matrix & $\begin{array}{l}\text { In the matrix structure, reporting relationships are set up as a grid or } \\
\text { matrix that rely on the principle of double subordination of agents: on } \\
\text { the one hand, agents report to the permanent head of a functional unit or } \\
\text { service who allocates resources (including staff), and on the other - } \\
\text { to the temporary head of a current project, who is endowed with the } \\
\text { authority to organize activities for certain programs. }\end{array}$ \\
\hline $\begin{array}{l}\text { Project- } \\
\text { oriented }\end{array}$ & $\begin{array}{l}\text { Project-oriented or projectized structure is adopted in order to assign } \\
\text { the maximum amount of resources to a specific project for a limited } \\
\text { period of time. It has the following characteristics: integrity of activities; } \\
\text { participation of various specialists who cooperate with each other; } \\
\text { clearly defined end result; limitations in time and resources allocated to } \\
\text { achieve development objectives. }\end{array}$ \\
\hline Network & $\begin{array}{l}\text { Network structure entails that the organization divides its main functions } \\
\text { (production, sales, finances, research and development) between } \\
\text { individual companies working under a contract with the help of another } \\
\text { small intermediary organization. }\end{array}$ \\
\hline
\end{tabular}

we may classify the organizational structure of the Catholic Church as one belonging to the bureaucratic type which is characterized by rigid hierarchical connections, centralized decision-making and a high degree of formalization [15, canons 332, §1,333, § 3, 334, 336].

This structure has been formed under the influence of historical conditions and meets the main dogmatic criteria of the Catholic Church concerning centralized management.

It is worth mentioning that the UGCC is a church sui iuris, which grants it privileges and a certain degree of autonomy in its organizational management [15, canons 55-62] In terms of the organizational structure of the UGCC, its status of a church sui iuris provides for the combination of centralized coordination via the Synod of the UGCC and patriarchal Curia with decentralized local-level management in archeparchies, eparchies, etc. Such OS is best reflected in a divisional structure into different regions, which is characterized by a combination of centralized strategic planning at the upper levels of management and decentralized activities of local-level management units, as indicated in Figure 3 [30; 36, p. 143-146, 153-156, 699-701]. 


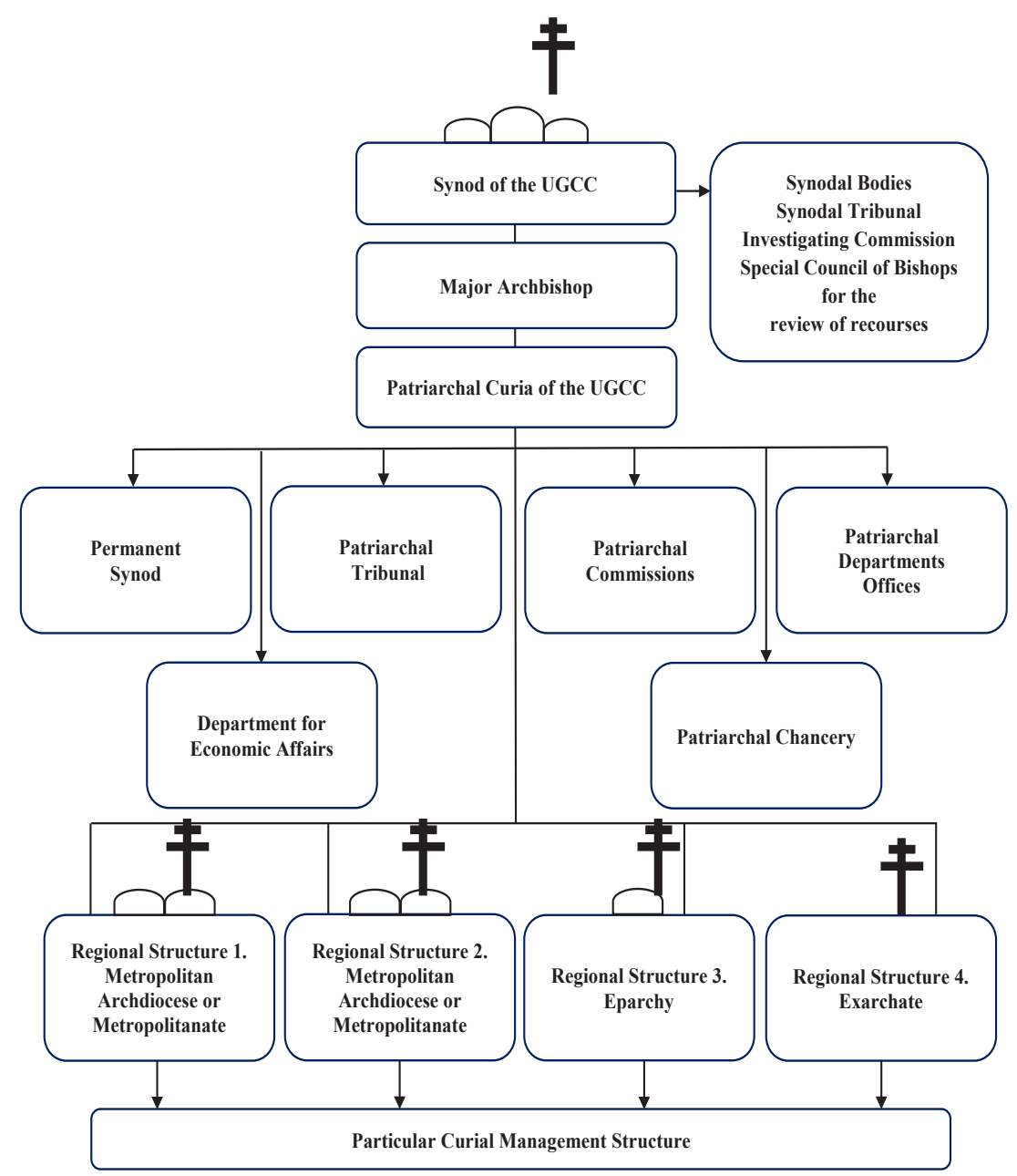

Figure 3. OS of the UGCC

\subsection{Organizational structure of the UGCC}

The study of the organizational structure of the UGCC requires the understanding of its peculiarities. The UGCC traces its history from the signing of the Union of Brest in 1596, which led to the accession of the Kyiv 
Orthodox Church initially characterized by collegiality, i.e. co-management of senior clergy. After the Union, the management took more centralized form due to the centre in the Vatican, which resulted in significant changes in the organizational structure of the UGCC. Unfortunately, while studying the OS of the UGCC researchers often use various terms that are similar in meaning but lack clear definition and standardization. In view of the historical aspects of the development of Christian churches, the development of the organizational structure of the UGCC took place at two levels of management: administrative-territorial and hierarchical or administrativemanagerial. Such division considers two main elements of OS of the UGCC: horizontal level encompasses the territory on which the UGCC has power while vertical level refers to the hierarchical nature of this church [6].

It should also be noted that, the general structure of the UGCC is divided into five hierarchical levels of management. On the first level, we may distinguish parishes headed by pastors as parochial administrators. On the second level, several parishes constitute a deanery under a dean [15, canons 279-281]. Subsequently, deaneries are managed by eparchial curias headed by a local eparchial bishop on the third level [15, canons 243-263]. On the fourth level, management apparatus over archeparchies is headed by metropolitans [15, canons 102, 133, 263-264, 270]. In the UGCC, the Synod with synodal bodies and patriarchal curia is situated on the fifth level of management, which is led by a patriarch or major archbishop [15, canons 110, 1006, 1062, 114-125)]. Furthermore, the UGCC recognizes the pope and Roman curia as the highest level of management [15, canons 279-281]. (see Figure 4).

Description of managing bodies of the UGCC. The UGCC, like other religious organizations, is a complex social institution the inner structure of which is based on the cooperation of various systems with a parish, i.e. organization of believers as its main element. Structural departments of the UGCC are liable for the management of parishes and coordination between them as well as the leadership, provision of certain services and assistance in the process of their development.

Main management bodies of the UGCC include:

1. The Synod, i.e. a council of bishops which acts as a legislative body.

2. Synodal bodies, which perform judicial, revisional and auditing functions of the highest instance. 


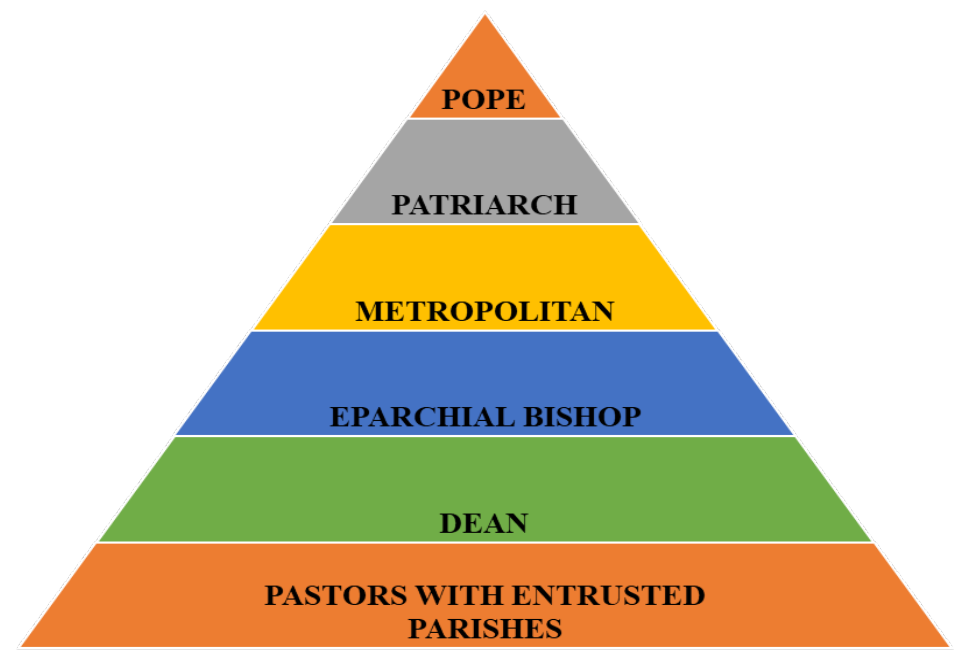

Figure 4. Levels of management in the UGCC

3. Patriarchal Curia, which includes executive bodies of the UGCC.

The Synod of Bishops together with the Major Archbishop of KyivHalych form the supreme ecclesiastical authority in the UGCC. The Synod of Bishops is a legislative body or council which comprises all bishops of the UGCC, i.e. those recently ordained and those who are not punished by canonical penalties. CCEC presupposes that others invited as guests or experts can take part in the Synod, albeit without the right to make an active vote on decisions [15, canon 102].

The Synod of the UGCC has the following functions:

- promulgation of laws for the UGCC;

- development of a program of pastoral service and missionary activities common to all structures of the UGCC and supervision over its implementation at local levels;

-involvement in the management of the UGCC through the establishment of synodal bodies and committees;

- delivery of justice due to its status as the highest religious tribunal;

- selection of a Head of the UGCC, bishops and other candidates for management positions; 
- acceptance of resignation of the head of the UGCC (Statute of the Synod of the UGCC, § 16).

The Synod of the UGCC is summoned at least once a year, and as of 2020, it comprises 49 bishops, 10 of which are bishops emeriti with a passive vote who remain lifelong members of the Synod [32, p. 121, 163, 225, 225, 295, $310,321,345,357,368,379,421,423,503,520,561,584,623,626,628$, 629, 634, 661, 677, 697, 705, 706, 729, 741, 792, 795, 1012, 1013].

Patriarchal Assembly of the UGCC is the supreme representative consultative council of the believers of the whole Church. The Assembly consolidates the bishops, other ordained clergy and believers. Its function is to assist the Major Archbishop and the Synod of Bishops in the solution of issues of greater gravity, especially in order to harmonize appropriately the forms and programs of the apostolate and ecclesiastical discipline with the current circumstances of the time. Taking into account the common good of its Church, the Assembly acts as a forum for negotiating and expressing opinions under the idea of religious freedom and responsibility [15, canon 40].

The Assembly is convoked and presided by the Major Archbishop of the UGCC once every five years [15, canon $142, \S 1]$.

Tasks of the Assembly:

1) to analyze and determine the main areas of Church activities in all aspects of the life of its believers;

2) to propose the major archbishop and the Synod of Bishops possible solutions to various issues and challenges in the life and activity of the Church;

3) to respond to the current conditions in order to spread the Christian faith;

4) to find appropriate ways of cooperation between the Church and society, as indicated in the Statute of the Patriarchal Assembly of the UGCC, paragraphs 1-4.

Synodal bodies of the UGCC. Synodal management of the UGCC provides for the creation of synodal bodies independent of the executive power of the Patriarch. Such bodies represent the general interests of the Synod of the UGCC as the managing body of the highest level which acts within the scope of its competence, as defined by the CCEC and the internal statute. Synod of the UGCC has a right to establish synodal bodies on a permanent or temporary basis. 
It is obligatory to create permanent synodal bodies comprising:

- Synodal tribunal;

- Investigating commission;

- Special council of bishops for the examination of issues concerning disapproval of major archbishop's administrative degrees.

Synodal bodies allow for a possibility of examining judicial, revisional, and supervisory issues concerning the highest levels of ecclesiastical authority.

Synodal tribunal. The Synod of Bishops of the UGCC is the Supreme Ecclesiastical Tribunal while retaining the jurisdiction of the Holy See and the prescriptions of the $1060^{\text {th }}$ of the CCEC. The Synod of the UGCC delivers justice within the boundaries of canonically defined territory on the third and fourth levels of the Ukrainian judicial system. The synodal tribunal is one of permanent synodal bodies formed by the Synod of Bishops of the UGCC, where a general moderator for the administration of justice, as well as two bishops who with him constitute a tribunal are elected by secret ballot for a five-year term. This tribunal is to judge the contentious cases either of eparchies, bishops or even titular bishops and its decisions are conclusive and cannot usually be appealed to. However, the canon $1056 \S 1$ states that any Christian faithful is free to bring a case at any stage and in any grade of judgment before the Roman Pontiff since he is the supreme judge for the entire Catholic world. In addition, the General Moderator for the Administration of Justice has the right of vigilance over all tribunals within the territorial boundaries of the patriarchal Church [15, canon 1062, § 1-5].

Synodal Revisional Commission of the UGCC. Synodal Revisional Commission is one of permanent synodal bodies created by the Synod of the UGCC. Its function is to provide a professional examination of the annual Report of the Patriarchal Finance Officer, which is later submitted to the Synod of Bishops of the UGCC. Besides, other tasks of economical nature on the level of the whole Church may be given to the revisional commission by instructions of the Synod or the Head of the UGCC.

Special council of bishops for review of recourses (appellations) against administrative decrees of the Father and Head of the UGCC. This synodal body is tasked with reviewing recourses against administrative acts (decrees) of the highest ecclesiastical authority, i.e. the patriarch. In the area of competence of this special council of bishops lies the ratification, repeal, withdrawal for further correction, and validation of decrees from a 
higher ecclesiastical authority without making amendments in its content [15, canon 124].

According to its statute, the Synod of the UGCC can also establish other temporary synodal bodies performing functions of professional examination, elaboration or solution of important cases in the UGCC which are then to be presented before the Synod of the UGCC.

Executive bodies of the UGCC. The Major Archbishop of Kyiv-Halych embodies the highest executive and representative authority in the UGCC. Executive functions are performed on his behalf by the Patriarchal Curia, which has the following responsibilities: to manage the current activity of the UGCC, to execute the decisions made by the Synod of Bishops of the UGCC, to develop and submit to the Synod of the UGCC drafts of laws and decisions important to the development or activity of the UGCC [15, canon 114].

The Patriarchal Curia serves as the central executive and advisory management body of the UGCC. Main tasks of the Patriarchal Curia of the UGCC:

- To act in the best interest and for the good of the UGCC:

- To implement decisions and decrees of the Synod of Bishops of the UGCC as well as the precepts, decrees, instructions and other legal acts concerning management from the Head of the Patriarchal Curia of the UGCC; Promote the establishment of relations between ordinary believers, monks and nuns, the clergy and hierarchs of the UGCC and religious organizations of the UGCC and secular authorities, bodies of local selfgovernment, religious and public international organizations, individuals and legal entities (Statute of the Religious organization 'The control centre' of the Patriarchal Curia of the UGCC, § 1.7-1.11).

The Patriarchal curia of the UGCC is created on the basis of a legal act of the Head of Patriarchal curia and functions according to the Statute of Patriarchal curia which is authorized by the Head of Patriarchal curia and registered in the public authority bodies.

The Patriarchal Curia comprises:

- The Permanent Synod of bishops;

- The Secretary of the Synod of Bishops;

- The Patriarchal Tribunal;

- The Patriarchal Chancery;

- Information Department:

- other commissions and departments [15, canon 114, §1]. 
Activities of the functional departments of the Patriarchal Curia are regulated by the common and particular law, their own guidelines and the Statute of the Curia of the Father and Head of the Church [26, § 75].

The Permanent Synod of Bishops is an elected body which represents the interests of the whole Church, as well as controls and regulates the activity of structures of the UGCC within its area of competence. The Permanent Synod comprises five bishops including the Father and Head of the UGCC who assembles it for a five-year period. The Permanent Synod is an advisory body on cases of regular management, planning, organization, motivation, and control in line with the general ecclesiastical legislation and the Statute [15, canons 115-120].

Patriarchal Tribunal. According to the CCEC, the Patriarch, i.e. the Major Archbishop has an obligation to establish an ordinary tribunal for the Patriarchal Church, distinct in functions from the Tribunal of the Patriarch's eparchy. The president and other members of this tribunal are appointed by the Patriarch with the consent of the Permanent Synod. This tribunal is the appellate tribunal for verdicts of metropolitan and eparchial tribunals which belong to a archdiocese of the UGCC. Patriarchal Tribunal is competent to examine cases pertaining to:

1. Exarchs and delegates of the Patriarch who are not bishops;

2. Physical or juridical persons immediately subject to the patriarch;

3. Institutes of consecrated life of pontifical right;

4. Superiors of institutes of consecrated life of pontifical right, who do not have a superior within the same institute who possesses judicial power;

5. Other cases reserved to this tribunal by a prescription of a particular law.

The patriarchal tribunal is the appellate tribunal for verdicts of metropolitan and eparchial tribunals which belong to an archdiocese of the UGCC [15, canon 1063, § 1-4].

The Secretary of the Synod of Bishops of the UGCC is an organisation department under the Patriarchal Curia of the UGCC aimed at assisting the Major Archbishop in arranging and carrying out Synods of Bishops of the UGCC and conducting all activities related to the Synod during a period between such meetings. The head of the secretary is elected by the Synod of Bishops of the UGCC among its members for a five-year term. The Secretary of the Synod comprises: the secretary of the synod, deputy secretary, archivist, and other members [26, § 8-12 ]. 
Administration is the main department providing for coordination and management over Patriarchal Curia. It is chaired by a person appointed by the Synod of the UGCC and approved by the Major Archbishop as specified in degrees and ecclesiastical laws.

The patriarchal chancery. The implementation of governing functions and the management over the activities of UGCC authorities requires proper documentation. Documents aimed at the regulation of UGCC activities are called administrative acts, issued by the executive authority within the limits of its competence after legitimate delegation. According to the $1510^{\text {th }}$ canon of the CCEC, there are following ecclesiastical administrative acts: decrees by which for a special case a decision is given or a canonical provision is made; individual precepts by which a person or determined persons are requested directly and legitimately to do or to omit something, especially pertaining to urging the observance of a law; rescripts by which a privilege, a dispensation, a permission or another favor is granted.

These tasks are assigned to the Patriarchal chancery, main functions of which is to compile, issue and send acts of the Curia for storage in the archive. The patriarchal chancellor and other members of the Patriarchal Chancery are appointed by the Head of the UGCC for three-year terms [15, canon 123].

The Department for Economic Affairs headed by patriarchal finance officer is another important element in the management of the UGCC.

The Department for Economic Affairs has the following functions: management over the goods of the Patriarchal Church, imposition of the principle of unity in matters of financial management, organization of the budget process, presentation of economic programs and reports [20].

It assists the patriarchal finance officer in his efforts to organize the proper and efficient management of goods and finances of the UGCC, and to create economic basis for the pastoral activity of the Patriarchal Curia. The Department for Economic Affairs consists of the following organisation departments:

- Accounting Department;

- Charity Department;

- Department of Economic Management;

- Department of Movable and Immovable Property.

The heads of these organisation departments are appointed by the Patriarch on patriarchal financial officer's submission [20]. 
The Patriarch, with the consent of the Permanent Synod, appoints a patriarchal finance officer for a five-year term [15, canon 122, § 2].

Patriarchal Assemblies. The aim of the Patriarchal Assemblies of the UGCC is to assist the Head of the UGCC in activities related to the propagation of the Church in Ukraine and abroad.

Patriarchal Assembly is a permanent consultative body of the Head and Father of the UGCC created by his decree. He convokes and presides at Patriarchal assemblies as well as appoints their members and deputies [15, canon 114, 124].

All Patriarchal Assemblies form a part of the Patriarchal Curia [15, canon $114 \S 1]$. and are guided by the common law, Canons of Particular Law of the UGCC, decisions of the Synod of Bishops, decrees and orders of the Head and Father of the UGCC. As of 2020, there are the following Patriarchal Assemblies:

- Patriarchal Assembly for Economic Affairs (Decree);

- Patriarchal Assembly for External Communications (Decree);

- The Pastoral Council of the Patriarchal Curia (Decree).

Patriarchal commissions, departments, and offices. The Synod of Bishops can establish various commissions in accordance with the needs of the Church so to make its activity more efficient. According to the CCEC, the Synod of Bishops must establish: the liturgical commission, catechetical commission, commission for missionary activity, commissions for ecumenism, as well as other structured required for the successful promotion of the mission of the Church. Structures established by the Synod of the UGCC belong to the Patriarchal curia and are guided by their own regulations and the Statute of the Curia of the Father and Head of the Church in addition of the common and particular laws. The presidents of such structures are appointed by the Father and the Head of the Church with the consent of the Synod of the UGCC [26, § 74-76].

The aim of the Patriarchal Commissions is to implement decisions and pronouncements passed at Synods and Assemblies of the UGCC. These structural units are responsible for the execution of tasks relating to their area of competence and also can propose drafts of various decisions to the executive bodies.

Patriarchal Commissions are established on the principle of representation, i.e. from the representatives of respective eparchial structures, while offices, bureaux, and departments are formed from specialists in various areas of religious or secular expertise. The appointment of heads and formation of 
the staff of these structures is performed by the Major Archbishop of the UGCC on the advice of the Permanent Synod. We may single out various functional departments in the general structure of the Patriarchal Curia, which act as important structural units and are responsible for different areas of development and activities in the UGCC (Shpaikher, 2010) (see table 3).

Table 3

Patriarchal Curia of the UGCC

\begin{tabular}{|l|l|l|}
\hline \multicolumn{1}{|c|}{ COMMISSIONS } & \multicolumn{1}{|c|}{ DEPARTMENTS } & $\begin{array}{l}\text { OFFICES AND } \\
\text { BUREAUX }\end{array}$ \\
\hline Catechetical & Of External Relations & $\begin{array}{l}\text { Pastoral And } \\
\text { Migration }\end{array}$ \\
\hline On Matters Of The Clergy & Of Information & Theological \\
\hline On Matters Of Monasticism & Live Television (Live.Tv) & Canonical \\
\hline Liturgical & $\begin{array}{l}\text { Voskresinnya } \\
\text { Resurrection) Live } \\
\text { Radio }\end{array}$ & Public Relations \\
\hline $\begin{array}{l}\text { Postulate Center Of The } \\
\text { Beatification And Canonization Of } \\
\text { Saints }\end{array}$ & $\begin{array}{l}\text { For Pastoral Care } \\
\text { In The Armed Forces }\end{array}$ & Social Affairs \\
\hline On Matters Of Youth & For Military Chaplaincy & $\begin{array}{l}\text { For Pastoral Care In } \\
\text { The Armed Forces }\end{array}$ \\
\hline On Matters Of The Family & $\begin{array}{l}\text { For Pastoral Care } \\
\text { In The Penitentiary } \\
\text { System }\end{array}$ \\
\hline On Justice And Peace & $\begin{array}{l}\text { Bureau } \\
\text { On Environmental } \\
\text { Issues }\end{array}$ \\
\hline For Promoting Christian Unity & & \\
\hline $\begin{array}{l}\text { On Christian Education And } \\
\text { Upbringing }\end{array}$ & & \\
\hline On Matters Of Pastoral Health Care & & \\
\hline On Matters Of The Laity & & \\
\hline On Matters Of Human Resourcing & & \\
\hline
\end{tabular}

The Patriarchal Curia plays an important role of organizer and coordinator on all levels of the aforementioned structures while establishing relations between them. The activity of the Patriarchal Curia is aimed at the development of the whole Church in Ukraine and abroad [31]. 
Therefore, the curias which belong to the third and fourth levels of management mostly have duplicated departments with common functional characteristics of Patriarchal structures, perform similar managerial functions and are formed depending on the needs and level of development of Church structures.

Despite peculiar circumstances, in particular, the separation from the state, unprofitability, the dependence on contributions and the constant search for resources, the contemporary organizational system and the structure of management in the UGCC have proven its ability for long-term development under the influence of a changing environment.

The question of the constant improvement of the organizational system and management apparatus should be viewed as a constant process of changes, the direction and nature of which will help to reveal the functional potential and potential of the UGCC management system in the future, an important aspect (prerequisite) in the process of development and survival of the UGCC.

\section{Conclusion}

At the end of 2019, the development of UGCC organizational structures and the scale of providing religious services showed significant growth as compared to the 1990s, which indicates a strong possibility of obtaining the status of patriarchate by the UGCC, the highest administrative and spiritual level of management and recognition in the Church. However, the process of globalization, as well as contemporary societal needs require an adequate response to the external environment and development of Church structures on part of the UGCC.

The key reasons for the ineffective functioning of religious organizations in Ukraine are organizational structures based on centralization, multi-level hierarchy, and the invariability of management methods.

The study of the organizational structure of the UGCC, as the largest Catholic church of the Eastern rite in the world, gave us an opportunity to look at the specifics of church management, responsibilities, the principle of construction and subordination of the basic elements of organizational structure and relationships.

In view of the above, it is necessary to highlight the following suggestions which may help improve the organizational structure of the UGCC, namely:

- introduction into the management system of strategic, medium- and short-term planning of the Church's development, both at the general and 
local levels, which will help to respond effectively and in a timely manner to changes in the external and internal environments;

- rationality of departmentalisation in accordance with the scale and areas of activity, and wider delegation of powers;

- improving the system of internal communication and communications;

- introduction of standardization of management processes and interaction between divisions of the organization and employees in these divisions.

Of course, the implementation of aforementioned objectives may be hindered by one's unwillingness or ineptitude to apply them in practice, which can lead to the process of stagnation and diminishment of the UGCC structures in the future.

\section{References:}

1. Azarova, T. V. \& Abramov, L. K. (2003). Menedzhment neprybutkovoi orhanizatsii [Management of a nonprofit organization]. Kirovohrad: TISC, ISCM.

2. Artomova, T. I. (2014). Nekomertsiyna sfera ekonomiky yak seredovyshche stanovlennia instytutiv rozvytku: svitovyy dosvid i realii Ukrainy [Non-commercial sphere of economy as an environment for the formation of development institutions: world experience and realities of Ukraine]. In: Bulletin of the Institute of Economics and Prognostics, 2-7.

3. Varava, L. M., Arutiunian, A. R., \& Varava, A. A. (2016). Stratehichni Aspekty Vdoskonalennia Orhanizatsiinoi Struktury Upravlinnia v Umovakh Hirnychobudivnykh Pidpryiemstv [Strategic aspects of improving the organizational structure of management in the conditions of mining enterprises]. In: Marketing and Innovation Management, 4, 243-255.

4. Heorhiadi, N. H., Vilhutska, R. B. (2012). Orhanizatsiina struktura upravlinnia yak skladova systemy menedzhmentu pidpryiemstva. In: Menedzhment ta pidpryiemnytstvo $v$ Ukraini: etapy stanovlennia i problemy rozvytku: [zbirnyk naukovykh prats] / vidpovidalnyi redaktor O. Ye. Kuzmin. Lviv: Vydavnytstvo Lvivskoi politekhniky, 33-34. (Visnyk / Ministerstvo osvity i nauky, molodi ta sportu Ukrainy, Natsionalnyi universytet "Lvivska politekhnika"; № 748). Retrieved from: http://ena.lp.edu.ua:8080/bitstream/ntb/23165/1/6-33-40.pdf

5. Hlushchevskyi, V. V., \& Smorodin, V. V. (2016). Rol' i mistse orhanizatsiinykh struktur u systemi upravlinnia pidpryiemstvom [Role and place of organizational structures in the enterprise management system]. In: Economic Bulletin of the Zaporizhzhya State Engineering Academy, 4(1), 70-76. Retrieved June 14, 2020, from: http://nbuv.gov.ua/UJRN/evzdia_2016_4(1)_16

6. Horan, T. A. (2016). Zminy v orhanizatsiinii strukturi Peremyshlskoi HrekoKatolytskoi Yeparkhii u 20-30-kh rokah 20-ho stolittya [Changes in the organizational structure of the Peremyshl Greek Catholic Eparchy in the 20-30s of the 20th century]. Halychyna. Retrieved June 15, 2020, from: http://nbuv.gov.ua/UJRN/ Nikp_2016_28_21 
7. Dekret zasnuvannya Dushpastyrskoyi rady Patriarshoyi kuriyi UHKTs [Decree on the founding of the pastoral Council of the Patriarchal Curia of the UGCC]. Retrieved June 11, 2020, from: https://synod.ugcc.ua/data/dekret-zasnuvannya-dushpastyrskoy-rady-patriarshoy-kuriy-ugkts-1077/

8. Dekret zasnuvannya Patriarshoyi rady z ekonomichnykh sprav [Decree on the establishment of the Patriarchal Council for economic affairs]. Retrieved June 13, 2020, from: https://synod.ugcc.ua/data/dekret-zasnuvannya-patriarshoy-rady-z-ekonomichnyh-sprav-355/

9. Dekret pro zasnuvannya Patriarshoyi rady social'noyi komunikaciyi UHKTs [Decree on the establishment of the Patriarchal Council for external communications of the UGCC]. Retrieved June 13, 2020, from: https://synod.ugcc.ua/data/dekret-pro-zasnuvannya-patriarshoy-rady-sotsialnoy-komunikatsiy-ugkts-899/

10. Dykan, N. V., Borysenko, I. I. (2008). Menedzhment. Kyiv.

11. Dymyd, M. (2012). Tymchasovyi Statut Patriarshoho Soboru Ukrainskoi

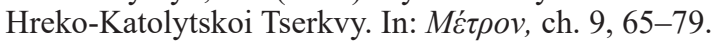

12. Didkovska, L. H., Hordiienko P. L. (2007). Menedzhment: navch. posibnyk. Kyiv: Alerta, KNT.

13. Istoriya UHKTs [History of the UGCC]. Retrieved June 17, 2020, from: http://ugcc.ua/official/ugcchistory/x_vidrodzhennya_tserkvi_1989_76327.html

14. Kanony Partykulyarnogo Prava Ukrayinskoyi Hreko-Katolytskoyi Tserkvy [Canons of the Particular Law of the UGCC]. Retrieved June 17, 2020, from: https://synod.ugcc.ua/library/canons/

15. Kodeks Kanoniv Shidnykh Tserkov (KKSTs) [Code of Canons of the Eastern Churches (CCEC)]. Retrieved June 13, 2020, from: http://dc.lviv.ua/nauka_cerkvy/ dokumenty/31-kodeks-kanonv-shdnih-cerkov.html

16. Meskon, M. Kh., Albert, M., Khedoury, F. (1992). Osnovy menedzhmenta / per. s anhl. Moskva: Delo.

17. Monastyrskyi, H. L. (2014). Teoriya organizatsiyi: pidruchnyk [Theory of organization: textbook]. Ternopil: Ternopil National Economic University.

18. Nazarova, H. V. (2004). Orhanizatsiy̆ni struktury upravlinnia korporatsiiamy: monohrafiia. 2-he vyd., dop. i perer. Kharkiv: VD "INZhEK".

19. Otrosh, M. I. Osoblyvosti mizhnarodnoyi pravosubyektnosti Svyatoho Prestolu [Features of the international legal personality of the Holy See]. Retrieved June 12, 2020, from: http://kul.kiev.ua/images/chasop/2013_1/ yyyyy/312.pdf

20. Polozhennya pro ekonomat ta byudzhetnyi protses Patriyarshoyi kuriyi UHKTs, Zatverdzheno Dekretom Holovy Patriyarshoyi Kuriyi UHKTs, Verkhovnoho Arhyyepyskopa Svyatoslava 15/200 vid 25 kvitnya 2015 roku [The regulation on the department for economic affairs and budget process of the UGCC Patriarchy as Approved by Decree of the Chairman of the UGCC Patriarchy, Supreme Archbishop Sviatoslav 15/200 of April 25, 2015].

21. Polozhennya pro sekretariat Synodu yepyskopiv UHKTs [Regulations on the Secretary of the Synod of bishops of the UGCC]. Retrieved June 22, 2020, from: https://synod.ugcc.ua/synod-of-bishops/secretariat/36/ 
22. Pro svobodu sovisti ta relihiini orhanizatsiyi: Zakon Ukrayiny [On freedom of conscience and religious organizations: Law of Ukraine]. Retrieved June 17, 2020, from: https://zakon.rada.gov.ua/laws/show/987-12\&

23. Putivnyk po Skhidnomu Kodeksu: Komentar do Kodeksu Kanoniv Skhidnykh Tserkov. (2008) / za red. Dzhordzha Nedungatta. T. 1.; az anhl. per. O. Hladkyi. Lviv: Svichado.

24. Statut Postijnogo Synodu Ukrayinskoyi Hreko-Katolytskoyi Tserkvy [Statute Of The Permanent Synod Of The Ukrainian Greek Catholic Church]. Retrieved June 16, 2020, from: https://synod.ugcc.ua/permanentsynod/statute/

25. Statut relihijnoyi orhanizatsiyi 'Kerivnyj tsentr «Patriarshoyi kuriyi» Ukrayinskoyi Hreko-Katolytskoyi Tserkvy [Statute of the religious organization 'The Control Centre' of the Patriarchal Curia of the Ukrainian Greek Catholic Church]. Nova redaktsiia. Ukraine, Kyiv.

26. Statut Synodu Yepyskopiv Ukrayinskoyi Hreko-Katolytskoyi Tserkvy [Statute of the Synod of bishops of the Ukrainian Greek Catholic Church]. Retrieved June 16, 2020, from: https://synod.ugcc.ua/synod-of-bishops/statute/

27. Statut Synodu UHKTs, parahraf 16 [Statute of the Synod of the UGCC, paragraph 16]. Retrieved June 15, 2020, from: https://synod.ugcc.ua/synod-of-bishops/statute/\#note-7

28. Typovyi statut Yeparkhialnoho Soboru [Standard Statute of the Eparchial Assembly]. Retrieved June 19, 2020, from: http://ugcc.ua/official/official-documents/instruktsiya/tipoviy_statut_yeparhialnogo_soboru_75581.html

29. Shorokhov, V. (2015). Osoblyvosti evolyucii organizaciynykh struktur upravlinnya pidpryyemstvom [Evolutionary characteristics of organizational structures of enterprise management]. Efficacy Public Administration, 44, 48-57. Retrieved June 17, 2020, from: http://www.lvivacademy.com/vidavnitstvo_1/edu_44/fail/ch_2/8.pdf

30. Shorokhov, V. (2015). Porivnialnyi analiz liniino-funktsionalnoi ta dyvizionalnoi orhanizatsiinykh struktur upravlinniaю In: Efektyvnist derzhavnoho upravlinnia, vyp. 43, 208. Retrieved from: http://www.lvivacademy.com/vidavnitstvo_1/ edu_43/fail/27.pdf

$\overline{3} 1$. Shcho take Patriarsha kuriia? Interviu iz vladykoiu Bohdanom Dziurakhom, kerivnykom Patriarshoi kurii UHKTs (2010). In: Patriiarkhat, no. 2.

32. Annuario Pontificio per l'anno (2020). Città del Vaticano, Libreria Editrice Vaticana 2020.

33. Daft, R. L., \& Lane, P. G. (2016). Management. Boston: South-Western College Publishing.

34. Drucker, Peter, F. (2004). Encyclopedia of Management. Moscow, Saint Petersburg-Kiev: Publishing house "Williams".

35. Eastern Catholic Churches Statistics. Retrieved June 13, 2020, from: https://cnewa.org/eastern-christian-churches/toc/eastern-catholic-churches-statistics/

36. Nedungatt, G. (2008). A Guide to the Eastern Code: A Commentary on the Code of the Canons Eastern Churches (O. Hladkyi, Trans.). Lviv: Svichado Publishing House. (Original work published 2002).

37. The Vatican Secretariat of State, \& Central Office of Church Statistics (2020). Annuario Pontificio 2020 [Pontifical Yearbook 2020]. Vatican Publishing House. 